\title{
Recuperating Ritual: Des Esseintes and the Crisis of - Modern Art
}

\section{R. Claire MAGAHA}

Tn the fourth chapter of J-K. Huysmans's A Rebours, we find many of the important themes that structure the entire work. In this part of the novel, the L protagonist, des Esseintes, displays his characteristic willingness to remain separated from society and to create an aesthetically agreeable space for himself within his country home. We may view this chapter of the book as a microcosm of the rest of the work, in that it is just one in a series of episodes in which des Esseintes attempts to find happiness through the cult of artifice. These efforts are creative ones, such as the cultivation of rare orchids, the creation of a jewelled tortoise shell, and the enshrinement of poetry: They occur in an asocial environment and are designed solely to elicit the pleasure of their creator. If des Esseintes occupies himself with creating art in this way, it is out of a desperate need to construct meaning, and, ultimately, to believe in his own immortality. Many critics have viewed this cult of artifice as a symptom of des Esseintes's neurosis. However, in the following study, I would like to suggest that this task is more appropriately a reaction to art's loss of the ritual function.

In his text, Illuminations, Walter Benjamin asserts that at the end of the 19th century, technology and its ability to reproduce all sorts of images brought about a crisis, since for the first time in history, non-religious art was more dominant than sacred art.

The secular cult of beauty, developed during the Renaissance and prevailing for three centuries, clearly showed that ritualis- 
tic basis in its decline and the first deep crisis which befell it. With the advent of the first truly revolutionary means of reproduction, photography, simultaneously with the rise of socialism, art sensed the approaching crisis which has become evident a century later. (224)

Art's genesis was no longer religion and its status as an offering to a deity had disappeared. It could be represented anywhere and was, therefore, separated from any tradition. The result was l'art pour l'art, or what Benjamin terms, "a theology of art" (224). In this scenario, art itself plays the role of the deity. Des Esseintes's reason for being is, indeed, to recuperate the Absolute quality of art. However, his art is created by him, for him, and in this case, we may view des Esseintes himself in the role of deity. Devastated by the fact that art no longer has a transcendent quality, he becomes a Creator in order to entertain notions of his own immortality. This task is naturally impossible. As we shall see, it is consistently thwarted by the intrusion of nature and the inability of his asocial art to take on universal meaning. Nature and society, then, prove fatal to des Esseintes's re-ritualizing intention.

Des Esseintes finds contentment only in those moments during which he believes in the power of artifice to dominate nature. Indeed, one of the rare happy moments he has in the novel is when he spies the tortoise moving about the dining room displaying its newly jewelled shell:

Des Esseintes regardait maintenant, blottie en un coin de sa salle à manger, la tortue qui rutilait dans la pénombre. Il se sentit parfaitement heureux; ses yeux se grisaient à ces resplendissements de corolles en flammes sur un fond d'or; puis, contrairement à son habitude, il avait appétit et il trempait ses rôties enduites d'un extraordinaire beurre dans une tasse de thé... (98)

This rush of joy inspires him to take part in his ritual of the orgue a bouche several minutes later. The passage that describes this experience is replete with religious allusions:

Il s'en fut dans la salle à manger où, pratiquée dans l'une des cloisons, une armoire contenait une série de petites tonnes, rangées côte à côte, sur de miniscules chantiers de bois de santal, percées de robinets d'argent au bas du ventre. Il appelait cette réunion de barils à liqueurs, son orgue à bouche. (99)

Des Esseintes's happiness is prolonged by this experience, but only momentarily. The sensations provoked by the whisky in his mouth remind him of having had a tooth removed by the local dentist:

Peu à peu, en buvant, sa pensée [...] réveilla, par une fatale exactitude d'odeurs, des souvenirs effacés depuis des ans. Ce fleur phéniqué, âcre, lui remémorait forcément l'identique sen- 
teur dont il avait eu la langue pleine au temps où les dentistes travaillaient dans sa gencive. (101)

The experience of the orgue à bouche, which is designed to be a personal, asocial ritual, has not served its intended purpose. Rather than securing his happiness, it has resuscitated through sensual correspondences the painful memory of his trip to the dentist. Nature and society once again take control of his environment, and his ritual space is destroyed.

In addition, it is important to note that the experiences of the tortoise and the orgue à bouche lack the collective quality of most rites. In fact, they remain unsatisfying precisely because they are not shared. Because they go unrecognized by others, they are not assigned a universal value and, as such, can never attain the status of art. How can des Esseintes believe in the value of his creations if no one else acknowledges them? They inevitably dissolve into nothingness, only to be followed by other, equally ineffective creative attempts.

Furthermore, it is not only because they lack a collective dimension that des Esseintes's efforts to re-ritualize art remain impossible, but because he himself is not completely convinced that re-ritualization is possible. His own doubts about religious faith and the existence of a God consistently undermine the spiritual quality of his endeavours. His will to create art is, thus, characterized by a double tension between the desire to attribute Absolute meaning to objects and experiences by ritualizing them, and the desire to rebel against any Absolute meaning of those objects and experiences. These conflicting desires can never be reconciled, and the dialectic that they create in the text is consistently broken by the intrusion of nature and society. Even if des Esseintes could truly believe in his art, nature and society would destroy it, and they do. Like the protagonist himself, his rituals cannot endure in his rarefied, asocial environment.

In conclusion, as he comes out of his reverie at the end of this chapter, he is faced with perhaps the most poignant reminder of his dependence on nature: the death of the tortoise. The animal has been unable to withstand the luxury that he imposed on it, and once again the illusion of his own personal society is shattered:

-Brou! fit-il, attristé par l'assaut de ces souvenirs. Il se leva pour rompre l'horrible charme de cette vision et, revenu dans la vie présente, il s'inquiéta de la tortue.

Elle ne bougeait toujours point, il la palpa; elle était morte. (103)

The death of the tortoise confirms nature's dominance over artifice, and this episode, like the rest of the text, is a testament to the protagonist's inability to obtain happiness through artistic creation. He has failed in his endeavour to overcome his neurosis by re-assigning a ritual function to art. He has not only been unable to dominate nature, but has been torn between his opposing desires 
to believe in ritual and reject it. In sum, in his solitude, des Esseintes cultivates his own demise, and inevitably learns what he already suspected: that the crisis that art underwent with the advent of technology can never be undone.

University of North Carolina at Chapel Hill 


\section{Works Cited}

Benjamin, Walter. Illuminations. New York: Schocken Books, 1968. Huysmans, J.-K. A Rebours. Paris: Garnier-Flammarion, 1978. 
